\title{
Evaluation of Stress Academic Levels of Medical Students of The South University Center. Case: Ciudad Guzman
}

\section{EVALUACION DE NIVELES DE ESTRES DE ESTUDIANTES DE MEDICINA DE LA UNIVERSIDAD DEL SUR. CASO: CIUDAD GUZMÁN}

Dra. Claudia Saldaña Orozco'; Luis Alberto De Loera Soto'; Dra. Berta Ermila Madrigal Torres ${ }^{1}$

1. Centro Universitario del Sur de la Universidad de Guadalajara.

\begin{abstract}
Objective: Identify the Factors associated to the academic stress of the student Population of the Medical School University Center in Mexico. Method: A descriptive correlational analysis was taken place starting with the implementation of the daily stress questionnaire (CED-44). The acquired results were the stress levels as much as general as the different social environments of the participants. In the study were included demographic factors and study levels. The measures were compared through the $\mathrm{T}$ tests for independent samples to determine the significant relation between the changeable and the stress levels. Results: The relation between the stress levels and the gender shows a major grade of influence of the stressful ones about the feminine gender. Likewise factors like the academic overload and the few time of recreation emphasize like the major stressful of the students population. Discussion and Conclussions: Prior to the latent psychosocial risk between University young students, it is suggested, the implementation of an initiative at stressors that at the time serves as motivational factor.
\end{abstract}

Key words: MENTAL HEALTH, ACADEMIC STRESS, PSYCHOSOCIAL FACTORS.

\section{RESUMEN}

Objetivo: Identificar los factores asociados al estrés académico de la Población de estudiantes de la Escuela de Medicina del Centro Universitario en México. Método: Se realizó un análisis correlacional descriptivo comenzando con la implementación del cuestionario de estrés diario (CED-44). Los resultados obtenidos mostraron niveles de estrés tan generales como los diferentes ambientes sociales de los participantes. En el estudio fueron incluidos factores demográficos y niveles de estudio. Las mediciones fueron comparadas por medio de pruebas $\mathrm{T}$ para muestras independientes para determinar la relación significante entre las variables y los niveles de estrés. Resultados: La relación entre los niveles de estrés y el género muestra un mayor grado de influencia de los estresados en el género femenino. Asimismo, factores como la sobrecarga académica y el poco tiempo de recreación enfatiza como la mayoría de la población estudiantil estresada. Discusión y Conclusiones: Antes del latente riesgo sicológico entre estudiantes universitarios jóvenes, se sugiere, la implementación de una iniciativa en los factores de estrés que al momento sirva de factor motivacional.

(Saldaña C, De Loera L, Madrigal B, 2017. Evaluación de Niveles de Estrés de Estudiantes de Medicina de La Universidad Del Sur. Caso: Ciudad Guzmán. Cienc Trab. Ene-Abr; 19 [58]: 31-34).

Palabras clave: SALUD MENTAL, ESTRÉS ACADÉMICO, FACTORES PSICOLÓGICOS.

\section{INTRODUCTION}

Within the academic field the daily circumstances are found vanished for the constant pressure that the students are found, ranging from the amount of responsibilities and the demand level, to mention some. The stress levels of the pupils are seen considerable altered for this fact, provoking consequences on their academic productivity. ${ }^{1}$

Correspondencia / Correspondence:

Dra. Claudia Saldaña Orozco

Universidad de Guadalajara, Ciudad Guzmán, Jalisco, México

López Mateos No. 33, Colonia Loma Bonita, Ciudad Guzmán, México

Tel.: +52 341883669 • Fax: 5752222 Ext. 46136

e-mail: claudias@cusur.udg.mx

Recibido: 18 de Noviembre de 2016 / Aceptado: 25 de Enero de 2017
According to Lazarus ${ }^{2}$ the psychological stress is defined an imposition as "a particular relation, that is evaluated for the person as an imposition or exigency or like something that exceeds their resources, putting in danger its welfare".

It is considered that the academic results are inside the general answers by the stress and do not represent a cause of the stress itself. ${ }^{3}$ Meaning that the negative results of the academic performance are the product of the stress conditions to whom the students are being submitted.

Speaking of the stress it is impossible not to mention Hans Selye. His investigations made a step to a sequence of inquires that gradually inclined towards the branches of the Psychology and Sociology while Selye was accepting the physical answers of the body towards the stress, others investigators decided for the analysis of the daily events to consider the major stressing factors.

These factors of psychological and subjective nature, are induced for our perception and interpretation of events and experiences. ${ }^{4}$ 
This way, it is understood that the stress is not determined by the individual or by the interaction with its ambient but for the particular relation that shows between both. ${ }^{5}$ The answer to the stress is mainly mental, consists in cognitive processes consequents of externs incentives. These processes have like an end to face the demanding situations and allow a quick reaction and adequate to the organism.

Nevertheless this answer supposes an important wear for the organism itself. If the situation shows of episodic manner, it will not be major physiological repercussions, but if the event is repeated with excessive frequency, intensity or length, could show up important psychological disturbances. ${ }^{6}$

Some authors, like Marlach and Jackson (like is quoted in Rodriguez Garza et al 2014) ${ }^{7}$ they consider the stress like a syndrome that was made by three dimensions.

- Emotional fatigue, related with somatic manifestations and psychological (depression, anxiety, irritability, to mention some)

- Depersonalize, related to the development of negative attitudes.

- Diminution of personal fulfilments, which is related with the limited or null perception of possibilities to get achievements.

The contributions of John Mason to the studies of Selye allow the consideration of the emotional factors as we determine in the stress answer. The subjective interpretation (in this case, noxious) of an incentive or situation by the individual leads to a psychosocial reaction that searches to fight the stress. ${ }^{5}$ This is why that the perception that the individual has of him or his situation results an extremely prominent element on what the psychosocial factors and measures of the stress is refer to.

To this respect, the threatening of the modern society can be related with factors like the competitive labor, the traffic, the noise, the marital disputes or the children's education. ${ }^{8}$ In the same manner, it is important to consider between these factors the economic difficulties, the intimacy of the couple, the political and social events and the academic training.

About the latter, during of all the academic lapse starting from the School grades until the academic level, a person that is in a period of learning tension experiments. To this condition is called present academic stress as in the individual study as in its own classroom. ${ }^{9}$ The difficulty and the exigence level of the different study programs take the pupils to experiment three types of stress. Then American psychologist Richard Lazarus ${ }^{10}$ identifies three stress types: that one who originates from the damage, saying, for the past events and they resulted in some damage, the one that threatens, that occurs when the individual is exposed to a situation that could cause him some damage in a near future and finally the challenge, that mobilizes the person to fight against his obstacles, but unlike of the threaten, it is valued like an opportunity benefit.

Again, the perception plays a fundamental role, Lazarus says that, depending of the individual, the same situation can be interpreted like threaten or challenge. Retaken the academic aspect, different studies point to the Medicine schools like one of the academic program of the major requirement. ${ }^{7}$ The big efforts point the adaptation to those who are submitted the Medical students like "a state of physical and emotional exhaustion and cognitive produced for the long involvement in situations generated of stress".

The theme is described American universities like Tuffs and Harvard which studies point that two third of the total stressors that support the medicine students derived specifically of the academic life and of social factors associated to it. ${ }^{11}$
The evolution of the studies that address the social factors of the stress generators have been a growing process. The psychiatrist Tomas H. Holmes was an important contributor at the study of the stressors, between 1957 and 1981. He was a part of different investigations that allow him to develop a framework of evaluation of the stress known as Inventory of Recent Experience (SER by his acronym in English). This questionnaire pretended to reflect the social load that the subjects are seen submitted and how this has negative repercussion in his health. ${ }^{8}$ The contributions of Holmes allowed to take the evaluation if the psychosocial factors to the different scenarios in which the people are seen immersed, between them, the academy ambit.

In a later study ${ }^{12}$ they develop a validation of reliability of its measurement, applying it to a total of 128 Psychologist students and comparing the result with the application of the Somatic Scale symptoms. The intention of the study was to discard somatic variables that could compromise the results of the instrument, mainly the neuroticism. Their conclusions point to the impossibility to convert a measure of self-report (lilke is itself CED-44) in a measure merely objective, but at discard the neuroticisms a pollutant factor of the test, the predictive validity of the mentioned instrument tends to be positive. ${ }^{13}$

With the intention to perform preventive strategies against the stress, Pulido Rull ${ }^{14}$ has found that the stress load is contrasting in the different educational programs of the Intercontinental University of Mexico City, since that some like Technology and Systems or Graphic Design record the major levels in comparison with the Tourism Bachelor or Law, whose standards are the lowest. The same way the academic overload seems to concentrate at the first and last semester of bachelor's degree given place to a decompensation with the central semesters.

In another study realized by Arribas Marin ${ }^{15}$ with nursing students, it breaks down a stress analysis from the perspective of the academic context. In this, they consider four dimensions that determine the stress level: mandatory works, academic overload, perception of the professor and perception of the subject. At the same time that in the raised theory, special importance is given to the situational perception of the student himself as a conclusive factor to the stressors. Likewise, the preponderant potential, emphasize of some subjects like stress sources.

That is why it must be understood the stress since a collective perspective, because the capacity of the individuals to deal their problems is seen influenced by the social scenarios where is immerse (between those that emphasize the ones already mentioned) which are designed to develop the abilities and competition required to get over the requirements on his environment. ${ }^{8}$

Psychological studies focuses on the health have determined that the self-perception or self-sufficiency that the individual has to himself be psychologic determinants to what stress refers. As noted Cabanach ${ }^{16}$ "if the persons believe they can manage with effectiveness the potential environmental stressors and perceive control over those stressors, these will be hardly considered as disturbing or adverse for this person".

The consequences related with the prolonged exposure to situations of stress have the negative impact of the mental health. The psychosocial factors and own conditions of the university life keep a close proximity with mental deterioration of the students causing stress condition and anxiety to mention some. ${ }^{17}$

The Medical Schools are considered as one of the most demanding for the students. Thus, determine the psychosocial factors and self- 
perceived levels. It is fundamental to plan strategies of intervention to prevent possible negative consequences of the University student's health.

The objective of the present study is to determinate the threaten level of the academic environment of the students mental health and the sociodemographic variables with major propensity to suffer it, whereby an achieved structure an intervention plan, in benefit of the own students and a renovation of the study plans, as well as, pedagogic strategies applied in the Medical schools.

\section{MATERIALS AND METHODOLOGY}

It was carried out a quantitative study of correctional descriptive character, with the intention to find association between the stress levels of the Medical students of a South University School in Jalisco and its sociodemographic variables.

The study sample was integrated by 262 students with the bachelor's degree in Medical Surgeon and midwife of the South University Center of Ciudad Guzman, Mexico, selected through aleatory single sample to which questionnaire of daily stress was applied. ${ }^{12}$ The age of the participants ranges between the ages of 18 to 27, belonging to all degrees of the Medical School.

The instrument selected for their application was Questionnaire of Daily Stress (CED-44). Such instrument is an abbreviated version comprising of 44 items or events that usually occur to the people in a daily more or less way, The individual most indicate in what media the described questionnaire seemed negative in the last 30 days, since "nothing negative" to 5 very negative. Also to the global punctuation, allows obtaining punctuations in seven different dimensions:

1) Leisure and intimacy

2) Work

3) Social and intellectual aspects

4) Couple and home

5) Homework

6) Economic and family aspects

7) Environmental aspects

It has been made a descriptive analysis of the variables obtained, whose data was expressed on frequency tables, in accordance with its relevance. Relations were established between the variables and the stress score proportionated by the instrument through a test $\mathrm{T}$ for independent samples. The significate value was established on $\mathrm{P}<0,05$. The statistical calculation was realized with the program SPSS version 15.0

\section{RESULTS}

Then it shows the variables of the sample taken starting with the application of the questionnaire (Board 1). It is noted, a balance exists as to the total of men and women in the sample, with a division of $50 \%$ by genre, a to the distribution by school semester, the major percentage is concentrated in the first grade, with the $27,1 \%$ The rest of the semester maintain an approach of constant percentile. The general stress levels shows a 20\% of the population with levels between "half" and "a very negative", meanwhile the higher percentage (46\%) is concentrated in the stratum "Little negative" (Board 2). The $\mathrm{T}$ proof for independent samples showed a significate association between the stress levels and the gender of the participants, with a value of .031 of bilateral significance. In the other side, the same proof did not show a relevant relation between the stress levels and the academic degree at the students (Board 3).

The instrument dimensions shows a clear inclination of the stress levels toward the ambit of homework whose 40\% ranges between moderately and very negative. Immediately below, the dimensions of Leisure and Intimacy, are found, with a negative load of 33\% In contrast, dimensions as Economic and familiar aspects, Couple and home and Social and intellectual aspects do not seem to contribute to the stress levels of the participants (Board 4).

\section{DISCUSSION}

The results show that the women students have a major inclination towards de academic stress in comparison with men. In despite that the stress conditions have negative consequences in both genders; women show a general trend to feel pressured for the conditions of their academic environment, family and social.

Meanwhile, though the study levels did not show any contrasting difference, the first year showed a light stressful inclination over the others school grades, consequence of the sudden work load to which they are subjected the students of recently entry to the university life. As suggests Rodriguez Garcia et $\mathrm{al}^{10}$ an early intervention against the stress in this academic stage will allow to progress in the development of strategies to prevent psychosocial risks involved.

As a proof of this, the instrument stands that the school responsibilities represent the major stressor between the students of the Medical school, above of dimensions like the work, economic and family aspects. In a close relationship a dimension of leisure and intimacy is found who's percentage of stress suggest that the lack of free time for coupled recreation to the surcharge school work, intensities the stressors effects. In some reagents of the instrument can be appreciated stress indices major to $25 \%$ between the ones most notably those related with the physical appearance and the lack of economic resources to leisure activities.

The main detractor that contributes to increase the negative perception of the stressors is the lack of a program of intervention that guides to the students to fight with the circumstances, as academic as daily that it could mean harmful psychological load. According to Arribas Marin ${ }^{15}$ the perception that the student himself has of his situation is a determinant factor as far as the stress level is referred, so train the study community to assimilate the conditions of his environment to reduce the stress levels and contribute to a better academic performance.

The predisposition of the student towards the academic overload which it is known that he will be subject, together with the various present stressors in the development of his daily life are elements that represent a threaten to the psychological health even before starting the school year. Here it is the importance to implement a confrontation initiative before potential stressors that at the same time serve as a motivational factor of students groups.

In conclusion, the dimension that increases in major measure the stress levels on the medical students is that one related with school works, closely related with the lack of time for the leisure and recreation. The female gender shows a major grade of stress in comparison with the male, while the school degree do not involve significate differences. An early intervention that focusses in the perception of the environment is most timely way to fight the psychological consequence causing the university students stress. 


\section{ANEXES}

Board 1.

Variables of the participants.

\begin{tabular}{|c|c|c|}
\hline \multicolumn{3}{|l|}{ Variables } \\
\hline \multirow[t]{3}{*}{ Gender } & Female & $132(50,4 \%)$ \\
\hline & Male & $130(49,6 \%)$ \\
\hline & & Total: 271 (100 \%) \\
\hline \multirow[t]{7}{*}{ Semester } & $1^{\circ}$ & $71(27, \%)$ \\
\hline & $2^{\circ}$ & $38(14,5 \%)$ \\
\hline & $3^{\circ}$ & $47(17,9 \%)$ \\
\hline & $4^{\circ}$ & $38(14,5 \%)$ \\
\hline & $5^{\circ}$ & 31 (11,8 \%) \\
\hline & $6^{\circ}$ & $37(14,1)$ \\
\hline & & Total: $262(100 \%)$ \\
\hline
\end{tabular}

Board 2.

Stress Levels.

\begin{tabular}{lc} 
Stress level & Percentage \\
\hline Nothing negative & $31,3 \%$ \\
Slightly negative & $46,9 \%$ \\
Moderately negative & $18,7 \%$ \\
Quite negative & $2,3 \%$ \\
Total & $100 \%$
\end{tabular}

Board 3.

T proof for equality gender measures.

\begin{tabular}{|c|c|c|c|c|c|}
\hline$t$ & $\mathrm{gl}$ & Sig. (bilateral) & Unlike measures & Error of the difference & $\begin{array}{l}95 \% \text { confidence interval for the difference } \\
\text { Inferior } \\
\text { Superior }\end{array}$ \\
\hline 2,163 & 259 & 0,031 & 6,522 & 3,015 & 12,460 \\
\hline 2,165 & 25,031 & 0,031 & 6,522 & 3,012 & 12,454 \\
\hline
\end{tabular}

Board 4.

Dimensions of the instrument.

\begin{tabular}{|c|c|c|c|c|c|}
\hline Dimensions / Scale & Nothing negative & Slightly negative & Moderated negative & Quite negative & Very negative \\
\hline Leisure and intimacy & $24,8 \%$ & $40,8 \%$ & $24.4 \%$ & $8 \%$ & $1,9 \%$ \\
\hline Work & $43,5 \%$ & $31,7 \%$ & $16 \%$ & $6,5 \%$ & $1,9 \%$ \\
\hline Social and intelectual aspects & $48,1 \%$ & $24,4 \%$ & $18,7 \%$ & $5 \%$ & $3,1 \%$ \\
\hline Couple and home & $56,9 \%$ & $21 \%$ & $17,2 \%$ & $3,8 \%$ & $0,4 \%$ \\
\hline Homework & $20,6 \%$ & $37,4 \%$ & $24 \%$ & $13 \%$ & $4,6 \%$ \\
\hline Economical and family aspects & $28,2 \%$ & $48,1 \%$ & $16,4 \%$ & $6,1 \%$ & $0,8 \%$ \\
\hline Enviromental Aspects & $46,6 \%$ & $28,2 \%$ & $16,4 \%$ & $5,7 \%$ & $3,1 \%$ \\
\hline
\end{tabular}

\section{REFERENCIAS}

1. Maldonado MD, Hidalgo MJ, Otero MD. Programa de intervención cognitivo-conductual y de técnicas de relajación como método para prevenir la ansiedad y el estrés en alumnos universitarios de Enfermería y mejorar el rendimiento académico. Cuad Med Psicosom Psiquiatr Enlace. 2000; (53):34-57.

2. Lazarus RS, Folkman S. Stress, appraisal and coping. Nueva York: Springer Publishing Company; 1984.

3. Román $C A$, Ortiz F, Hernández Y. El estrés académico en estudiantes latinoamericanos de la carrera de Medicina. Rev Iberoam Educ. 2008; (46):1-8.

4. Reynoso 0 , Méndez TE. Aproximación al estudio del estrés y la depresión: procesos psicosociales y psicofisiológicos. En: Galán S, Camacho EJ. Estrés y salud. Investigación básica y aplicada. México: Manual Moderno; 2012. p. $29-43$.

5. Rivera LD. Los sindromes de estrés. Madrid: Sintesis; 2010.

6. González RR, Doval YR, Pérez OM. Estrés laboral, consideraciones sobre sus caracteristicas y formas de afrontamiento. Rev Int Psicol. 2002; 3(1):1-19.

7. Rodriguez MD, Sanmiguel MF, Muñóz A, Rodríguez CE. El estrés en estudiantes de medicina al inicio y final de su formación académica. Rev lberoam Educ. 2014; (66):105-122.

8.- Sandin B. El estrés: un análisis basado en el papel de los factores sociales. Int J Clin Health Psychol. 2002;(3):41-157.
9. Orlandini A. El estrés, qué es y cómo evitarlo. México: Fondo de Cultura Económica; 1999.

10. Lazarus RS, Lazarus BM. Pasión y razón; la comprensión de nuestras emociones. Barcelona: Paidós; 2000.

11. Polo $A$, Hernández J, Pozo $C$. Evaluación del estrés académico en estudiantes universitarios. Ansiedad estrés. 1996; (2):159-172.

12. Santed M, Sandin B, Chorot P. Cuestionario de Estrés Diario (CED): Validez de constructo y el problema de la confusión de medidas. Bol Psicol. 1996; (51):45-70.

13. Santed MA, Sandín B, Chorot P. Predicción de la sintomatologia somática a partir del estrés diario: un estudio prospectivo controlando el efecto del neuroticismo. Rev Psicopatol Psicol Clin. 2000; 5(3):165-178.

14. Pulido MA, Serrano ML, Valdés $E$, Chávez MT, Hidalgo P, Vera F. Estrés académico en estudiantes universitarios. Psicol Salud. 2011; 21:31-37.

15. Arribas J. Hacia un modelo causal de las dimensiones del estrés académico en estudiantes de Enfermería. Rev Educ. 2013.533-556.

16. Cabanach $G R$, Valle $A$, Rodríguez $S$, Piñeiro I, González P. Las creencias motivacionales como factor protector del estrés en estudiantes universitarios. Eur J Educ Psychol. 2010; 3(1):75-87.

17. Gutiérrez Rodas JA, Montoya Vélez LP, Toros Isaza BE, Briñón Zapata MA, Rosas Restrepo E, Salazar Quintero LE. Depresión en estudiantes universitarios y su asociación con el estrés académico. CES Medicina. 2010; 24(1):7-17. 